\title{
УРАЖЕННЯ ЩИТОПОДІБНОЇ ЗАЛОЗИ У ХВОРИХ НА ХРОНІЧНИЙ ГЕПАТИТ С ТА ЇХ ВЗАЕМОЗВ'ЯЗОК ЗІ ЗМІНАМИ ОРГАНОНЕСПЕЦИФІЧНИХ АВТОАНТИТІЛ
}

\author{
Запорізький державний медичний університет
}

\begin{abstract}
Хронічний гепатит C, на відміну від гепатитів іншої етіології, характеризується високою частотою розвитку позапечінкових проявів. Роль імунних порушень в розвитку HCV-асоційованих уражень щитоподібної залози на сьогодні вивчається.

мета роботи - визначити особливості ураження щитоподібної залози у хворих на хронічний гепатит С та дослідити їх взаємозв'язок зі змінами органонеспецифрічних автоантитіл.

Пацієнти і методи. В дослідження було включено 225 хворих на хронічний гепатит С. Для діагностики ураження щитоподібної залози досліджували вміст у сироватці крові тиреотропного гормону, вільного трийодтироніну, вільного тироксину, антитіл до тиреоїдної пероксидази, антитіл до тиреоглобуліну. Спеціальні методи дослідження включали визначення вмісту в сироватці крові: антинуклеарних антитіл, ревматоїдного фактора, кардіоліпіну IgM ma IgG, циркулюючих імунних комплексів.
\end{abstract}

Результати. У 19,6 \% хворих на хронічний гепаmuт С розвивається ураження щитоподібної залози, що проявляється змінами у крові вмісту тиреотропного гормону, вільних тироксину і трийодтироніну, появою лише органоспецифрічних автоантитіл або поєднанням зазначених змін. Переважає розвиток гіпотиреозу (68,2 \%). Ураження щитоподібної залози розвивається частіше у жінок, ніж у чоловіків (32,1 проти 8,4 \%, p<0,01). У хворих на хронічний гепатит С з ураженням щитоподібної залози, на відміну від пацієнтів без цього прояву, частіше виявляються антинуклеарні антитіла, вищий вміст кардіоліпіну IgM й IgG, а рівень підвищення антитіл до тиреоїдної пероксидази корелює $(p<0,01)$ з вмістом ревматоїдного фрактора IgM $(r=+0,66)$ та кардіоліпіну IgM $(r=+0,39)$. Наявний прямий кореляційний зв'язок між кількісним вмістом антитіл до тиреоїдної пероксидази та вмістом ревматоїдного фрактора RF-IgM $(r=+0,66 ; p<0,01)$ й вмістом кардіоліпіну IgM $(r=+0,39 ; p<0,05)$ підтвер- джує роль автоімунних порушень у формуванні HCVасоційованих уражень щитоподібної залози.

Висновки. У кожного п'ятого хворого на хронічний гепатит С розвивається ураження щитоподібної залози, що найчастіше характеризується як гіпотиреоз. За наявності ураження щитоподібної залози у хворих на хронічний гепатит С частіше виявляються кардіоліпін IgM ŭ IgG, антинуклеарні антитіла. Рівень підвищення антитіл до тиреоїдної пероксидази корелює 3 вмістом ревматоїдного фрактора IgM та кардіоліпіну IgM.

Ключові слова: хронічний гепатит C, щитоподібна залоза, органонеспецифрічні автоантитіла.

Хронічному гепатиту C (ХГС) належить особлива роль у розвитку позапечінкових уражень. Це ствердження стосується як високої частоти цих проявів, так і особливостей їх спектра $[1,2]$. Позапечінкові прояви ХГС у ряді випадків можуть визначати тяжкість стану пацієнтів і прогноз захворювання в цілому. Іноді саме ці прояви ХГС, домінуючи в клінічній картині захворювання, стають головною причиною першого звернення хворих до лікарів різного профрілю, обумовлюючи складність діагностики та подальшого лікування. В одних пацієнтів позапечінкові ознаки можуть бути першими проявами хронічної HCV-інфекції, в інших - розвиваються через декілька років після виявлення збудника [3], при цьому в будьякому випадку вони підвищують ризик смерті $[2,4]$.

Дані сучасної літератури щодо HCV-асоційованого ураження щитоподібної залози свідчать, що тиреоїдні захворювання значно частіше реєструються у хворих на ХГС, ніж в загальній популяції [5]. Припускають безпосередню роль HCV у розвитку ураження щитоподібної залози за рахунок стимуляції синтезу ендогенного інтерферону- $\alpha$ у тканинах цієї залози, що є відображенням природженої імунної відповіді на вірусну інорекцію $[6,7]$.

У наукових дослідженнях, що присвячені вивченню механізмів розвитку позапечінкових проявів ХГС, осо- 
блива увага приділяється імунним реакціям, які виникають у відповідь на реплікацію HCV поза печінкою $[8,9]$. Проте провідне значення в системності уражень при ХГС відіграє лімсротропність вірусу з переважною його локалізацією в В-лімфоцитах. Доведено, що в результаті взаємодії антигенів HCV зі специфічними рецепторами В-клітин знижується поріг активації останніх, пригнічується їх апоптоз, внаслідок чого має місце моно- й поліклональна проліферація лімфоцитів з підвищеною продукцією автоантитіл, циркулюючих імунних комплексів (ЦІК) та змішаних кріоглобулінів $[10,11]$, що створює субстрат для імунопатологічних реакцій $[4,12]$. В ряді досліджень $[13,14]$ показано, що у більшості хворих на ХГС виявляються ті чи інші лабораторні ознаки автоімунних порушень, проте їх клінічне значення, за винятком змішаних кріоглобулінів, залишається недостатньо з'ясованим.

Мета дослідження - визначити особливості ураження щитоподібної залози у хворих на хронічний гепатит С та дослідити їх взаємозв'язок зі змінами органонеспецифрічних автоантитіл.

\section{Пацієнти і методи}

У дослідження було включено 225 хворих на ХГС віком від 19 до 60 років. Чоловіків - 119, жінок - 106. Всі пацієнти залучені в дослідження за випадковою ознакою та за інфрормованою згодою.

При постановці діагнозу ХГС користувалися класифрікацією хронічних гепатитів, запропонованою на Міжнародному конгресі гастроентерологів (Лос-Анджелес, 1994). Для діагностики ураження щитоподібної залози методом ІФА 3 використанням ELISA-наборів для кількісного виміру відповідно до методик, запропонованих виробниками, досліджували вміст у сироватці крові: тиреотропного гормону
(DRG, USA); вільного трийодтироніну (DRG, USA); вільного тироксину (MICROWELL ELISA, USA); антитіл до тиреоїдної пероксидази (DRG, USA); антитіл до тиреоглобуліну (DRG, USA). За наявності змін досліджуваних параметрів хворі були консультовані лікарями ендокринологами, за необхідністю проводилося УЗД щитоподібної залози.

Спеціальні методи дослідження включали визначення вмісту в сироватці крові: антинуклеарних антитіл (ANA) (MICROWELL ELISA, USA); ревматоїдного фрактора (RF) IgM та IgG (ORGENTEC, Germany); кардіоліпіну IgM та IgG (MICROWELL ELISA, USA); ЦIК (Hycult biotech, USA) методом ІФА з використанням ELISA-наборів для кількісного виміру відповідно до методик, запропонованих виробниками. ІФА виконано за допомогою імуноферментного аналізатора SIRIO S (Німеччина).

Статистичну обробку отриманих результатів досліджень здійснювали з використанням сорормованої бази даних обстежених пацієнтів і здорових осіб у програмі «STATISTICA ${ }^{\circledR}$ for Windows 6.0» (StatSoft Inc., № AXXR712D833214FAN5). Для оцінки достовірності різниці кількісних ознак застосовували критерій Манна-Уітні, якісних ознак - метод хі-квадрат $\left(X^{2}\right)$, для оцінки ступеня зв'язку між ознаками - метод рангової кореляції Спірмена.

\section{Результати досліджень та їх обговорення}

За результатами аналізу функціонального стану щитоподібної залози у кожного п'ятого хворого на ХГС (44 - 19,6 \%) виявлено лабораторні зміни, що свідчили про її ураження. Зміни біохімічних показників характеризувалися у 24 (10,7 \%) пацієнтів відхиленням від рефрерентних значень тільки вмісту гормонів, у 7 (3,1%) - появою лише органоспецифрічних автоантитіл без змін вмісту гормонів та у 13 (5,8 \%) - поєднанням вищезгаданих змін (табл. 1).

Таблиця 1

Зміни показників функціонального стану щитоподібної залози та органоспецифічних автоантитіл у хворих на ХГС

\begin{tabular}{|c|c|c|c|c|c|c|}
\hline \multirow{3}{*}{ Показник } & \multicolumn{6}{|c|}{ Хворі на ХГС (n=225) } \\
\hline & \multicolumn{2}{|c|}{ Підвищений вміст } & \multicolumn{2}{|c|}{ Знижений вміст } & \multicolumn{2}{|c|}{ Відсутність змін } \\
\hline & абс. число & $\%$ & абс. число & $\%$ & абс. число & $\%$ \\
\hline Вільний трийодтиронін & 8 & 3,6 & 29 & 12,9 & 188 & 83,5 \\
\hline Вільний тироксин & 2 & 0,9 & 5 & 2,2 & 218 & 96,9 \\
\hline Тиреотропний гормон & 16 & 7,1 & 1 & 0,4 & 208 & 92,5 \\
\hline Антитіла до тиреоглобуліну & 16 & 7,1 & - & & 209 & 92,9 \\
\hline Антитіла до тиреоїдної пероксидази & 14 & 6,2 & - & & 211 & 93,8 \\
\hline
\end{tabular}

У 29 (12,9 \%) пацієнтів відзначено зменшення вмісту вільного трийодтироніну в сироватці крові на 27,172,1 \% від нижчої межі референтного інтервалу цього показника. Рідше реєструвалося підвищення вмісту вільного трийодтироніну в сироватці крові на 16,7-56,7 \% від верхнього значення референтного інтервалу. У 5 $(2,2 \%)$ хворих зафріксовано зниження вмісту вільного тироксину в сироватці крові на 8,7-81,2 \% від нижньої 
межі референтного інтервалу цього показника. У двох пацієнтів відзначено підвищення вмісту вільного тироксину в сироватці крові в 2,5 та 4,7 разу, порівняно 3 верхнім значенням референтного інтервалу. Зміни периферійних гормонів поєднувалися у 16 (7,1%) пацієнтів 3 підвищенням вмісту в сироватці крові тиреотропного гормону від 11,1 \% до в 14,1 разу вище верхнього рівня референтного інтервалу. В одному випадку було зареєстровано зниження вмісту тиреотропного гормону в сироватці крові на 33,3 \% від нижнього рівня референтного інтервалу (табл. 1).

Органоспецифічні автоантитіла виявлено в сироватці крові 20 (8,9\%) хворих на ХГС. У 16 (7,1\%) пацієнтів вміст антитіл до тіреоглобуліну перевищував референтне значення на 10,6 \% і більше, максимально в 8 разів. У 14 (6,2 \%) пацієнтів було виявлено підвищення вмісту антитіл до тиреоїдної пероксидази в сироватці крові на 29,1 \% і навіть у 15 разів. У 6 (2,7 \%) хворих відзначено підвищення вмісту антитіл до тиреоглобуліну за відсутності змін антитіл до тиреоїдної пероксидази; а у 4 $(1,8$ \%) пацієнтів було підвищення вмісту антитіл до тиреоїдної пероксидази за відсутності змін антитіл до тиреоглобуліну. У 10 (4,4%) пацієнтів зафріксовано підвищення обох цих параметрів (табл. 1).

Аналіз функціонального стану щитоподібної залози у хворих на ХГС показав найчастіше наявність субклінічного гіпотиреозу (30 - 13,3\%), що встановлено винятково за результатами біохімічних досліджень, який у $20(8,9 \%)$ пацієнтів ссрормувався за відсутності органоспецифічних автоантитіл, а у 10 (4,4 \%) пацієнтів - при наявності антитіл до тиреоглобуліну та тиреоїдної пероксидази. Лабораторні ознаки гіпертиреозу мали місце у 7 (3,1\%) хворих на ХГС, при цьому у 4 (1,8 \%) за відсутності автоантитіл, а у 3 (1,3 \%) за наявності органоспецифічних автоантитіл. У 7 (3,1 \%) хворих на ХГС антитіла до тиреоглобуліну та тиреоїдної пероксидази в сироватці крові виявлялися без змін функціонального стану щитоподібної залози.

Проведений аналіз фракторів, що можуть асоціюватися з розвитком ураження щитоподібної залози у хворих на ХГС, показав чіткий взаємозв'язок зі статтю хворих. Серед хворих на ХГС ураження щитоподібної залози частіше $\left(X^{2}=19,96, p<0,001\right)$ діагностовано у жінок, ніж у чоловіків: у 32,1 проти 8,4 \% відповідно. Слід зазначити, що поява біохімічних ознак ураження щитоподібної залози у хворих на ХГС не залежала $(p>0,05)$ від таких фракторів, як генотип HCV, вірусне навантаження, наявність HCV-асоційованої змішаної кріоглобулінемії.

Аналіз частоти виявлення органонеспецифічних автоантитіл у сироватці крові хворих на ХГС залежно від наявності ураження щитоподібної залози показав відсутність статистично значущої різниці між досліджуваними групами в частоті позитивного ревматоїдного фактора - як RF-IgM, так й RF-IgG. Проте частота виявлення позитивних кардіоліпіну $\operatorname{IgM}\left(X^{2}=4,15, p<0,05\right)$, кардіоліпіну $\operatorname{lgG}\left(X^{2}=5,84, p<0,05\right)$ та антинуклеарних антитіл $\left(X^{2}=6,17, p<0,01\right)$ виявилася достовірно вище у хворих на ХГС з наявністю біохімічних ознак ураження щитоподібної залози, порівняно з пацієнтами без такого ураження (табл. 2).

Таблиця 2

Частота виявлення органонеспецифічних автоантитіл у хворих на ХГС залежно від наявності ураження щитоподібної залози

\begin{tabular}{|l|c|c|c|c|}
\hline \multirow{2}{*}{ Показник } & \multicolumn{4}{|c|}{ Хворі на ХГС $(\mathrm{n}=225)$} \\
\cline { 2 - 5 } & без ураження щитоподібної залози $(\mathrm{n}=181)$ & з ураженням щитоподібної залози ( $\mathrm{n}=44)$ \\
\cline { 2 - 5 } & абс. число & $\%$ & абс. число & \% \\
\hline RF-IgM & 151 & 83,4 & 39 & 88,6 \\
\hline RF-IgG & 164 & 90,6 & 42 & 95,5 \\
\hline Кардіоліпін IgM & 92 & 50,8 & 30 & $68,2^{*}$ \\
\hline Кардіоліпін IgG & 99 & 54,7 & 33 & $75,0^{*}$ \\
\hline ANA & 31 & 17,1 & 15 & $34,1^{*}$ \\
\hline
\end{tabular}

Примітка. * - різниця достовірна порівняно з хворими на ХГС без ураження щитоподібної залози $(p<0,05-0,01)$.

Порівняння кількісного вмісту ревматоїдного фрактора в сироватці крові хворих на ХГС залежно від наявності ураження щитоподібної залози показало відсутність статистично значущої різниці між досліджуваними групами як показника RF-IgM, так й RF-IgG. Проте кількісний вміст кардіоліпіну IgM й RF-IgG виявилися достовірно вищими у хворих на ХГС з наявністю ознак ураження щитоподібної залози (табл. 3).

У хворих на ХГС як з наявністю HCV-асоційованого ураження щитоподібної залози, так й без цього позапечінкового прояву кількісний вміст ЦІК у сироватці крові був достовірно вище за аналогічний у здорових 
ОРИГІНАЛЬНІ ДОСЛІДЖЕННЯ

осіб ( $<<0,01)$. Однак порівняння показника вмісту ЦІК у сироватці крові хворих на ХГС залежно від наявності ураження щитоподібної залози не зареєструвало статистично значущих відмінностей (табл. 3).

Кількісний вміст органонеспецисрічних автоантитіл у хворих на ХГС за наявності ураження щитоподібної залози, $\mathrm{Me}\left(\mathrm{Q}_{25}-\mathrm{Q}_{75}\right)$

\begin{tabular}{|l|c|c|c|}
\hline \multirow{2}{*}{\multicolumn{1}{|c|}{ Показник }} & $\begin{array}{c}\text { Хесрерентні } \\
\text { значення }\end{array}$ & $\begin{array}{c}\text { Хезорі на ХГС }(\mathrm{n}=225) \\
\text { залення щитоподібної }\end{array}$ & $\begin{array}{c}\text { 3 ураженням щитоподібної } \\
\text { залози }(\mathrm{n}=44)\end{array}$ \\
\hline RF-IgM, IU/ml & $<20$ & $147,6(79,4-215,7)$ & $153,7(89,4-241,4)$ \\
\hline RF-IgG, IU/ml & $<20$ & $157,8(96,1-230,5)$ & $167,9(97,9-227,4)$ \\
\hline Кардіоліпін IgM, MPL & $<15$ & $14,7(9,7-21,4)$ & $23,4(13,5-37,4)^{*}$ \\
\hline Кардіоліпін IgG, MPL & $<10$ & $15,8(8,2-26,6)$ & $25,7(9,7-37,1)^{*}$ \\
\hline ЦІК, mAU/ml & $184,8(156,8-197,3)$ & $345,6(214,2-597,5)^{*}$ & $517,7(317,5-670,7)^{*}$ \\
\hline
\end{tabular}

Примітка. * - різниця достовірна $(p<0,01)$ порівняно $з$ хворими на ХГС без ураження щитоподібної залози.

Проведений кореляційний аналіз дав змогу зареєструвати наявність прямого кореляційного зв'язку середнього ступеня між кількісним вмістом антитіл до тиреоїдної пероксидази та вмістом ревматоїдного фрактора RF-IgM ( $r=+0,66 ; p<0,01)$ й вмістом кардіоліпіну IgM $(r=+0,39 ; p<0,05)$.

Відповідно з даними сучасної літератури, HCV відіграє роль етіологічного чиннику в розвитку автоімунного тиреоїдиту у хворих на ХГС. Частіше у цих пацієнтів порушення фрункції щитоподібної залози виявляються лабораторно й характеризуються як гіпотиреоїдизм, 3 виявленням автоантитіл у 5-12 \% пацієнтів [15]. За даними іншого дослідження [5], близько 13,0 \% HCVінсікованих пацієнтів мають гіпотиреоїдизм та більш ніж 25,0 \% мають тиреоїдні автоантитіла. Про частіший розвиток HCV-асоційованого ураження щитоподібної залози у жінок, хворих на ХГС, повідомляють й інші дослідники [16]. Поява автоімунних порушень у хворих на ХГС, що підтверджується виявленням широкого спектра серологічних маркерів автоімунітету, дозволяє стверджувати про значну роль автоімунних механізмів у формуванні позапечінкових проявів, зокрема автоімунного тиреоїдиту $[14,17]$.

\section{Література}

1. Голубовська О.А. Епідеміологія та природний перебіг гепатиту С / О.А. Голубовська // Клінічна ендокринологія та ендокринна хірургія. - 2008. - № 4. - С. 1-3.

2. Marcellin P. Viral hepatitis: impressive advances but still a long way to eradication of the disease / P. Marcellin, T. Asselah // Liver International. - 2014. - Vol. 34, N 1. - P. 1-3.

3. Stefanova-Petrova D.V. Chronic hepatitis $C$ virus infection: prevalence of extrahepatic manifestations and association with cryoglobulinemia in Bulgarian patients / D.V. Stefanova-Petrova, A.H.

\section{Висновки}

1. У $19,6 \%$ хворих на ХГС розвивається ураження щитоподібної залози, що проявляється змінами у крові вмісту тиреотропного гормону, вільних тироксину і трийодтироніну (10,7 \%), появою лише органоспецифрічних автоантитіл до тиреоглобуліну і тиреоїдної пероксидази $(3,1 \%)$ або поєднанням зазначених змін (5,7 \%). Серед хворих з наявністю біохімічних ознак ураження щитоподібної залози переважає розвиток гіпотиреозу (68,2 \%). Ураження щитоподібної залози у хворих на ХГС розвивається частіше у жінок, ніж у чоловіків (32,1 проти 8,4 \%, $\mathrm{p}<0,01)$.

2. У хворих на ХГС з ураженням щитоподібної залози, на відміну від пацієнтів без цього прояву, частіше виявляються кардіоліпін $\operatorname{lgM}(68,2$ проти $51,1 \%$, р <0,05) й IgG (75,0 проти 55,0\%, p<0,05), антинуклеарні антитіла (34,1 проти 17,2\%, p<0,01), вищий вміст кардіоліпіну IgM й IgG ( $p<0,01)$, а рівень підвищення антитіл до тиреоїдної пероксидази корелює $(p<0,01) 3$ вмістом ревматоїдного фрактора IgM $(\mathrm{r}=+0,66)$ та кардіоліпіну IgM $(r=+0,39)$.

Tzvetanska, E.J. Naumova // J. Gastroenterol. - 2007. - Vol. 13, N 48. - P. 6518-6528.

4. Lee M.-H. Chronic hepatitis $C$ virus infection increases mortality from hepatic and extrahepatic diseases: a community-based long-term prospective study / M.-H. Lee, Yang Hwai-I., Lu Sheng-Nan // J. Infect. Dis. - 2012. - Vol. 206. - P. 469-477.

5. Antonelli A. Thyroid disorders in chronic hepatitis C / A. Antonelli, C. Ferri, A. Pampana // Am. J. Med. - 2004. - Vol. 117. - P. 10-13. 


\section{ОРИГІНАЛЬНІ ДОСЛІДЖЕННЯ}

6. Зінчук О.М. Ураження щитовидної залози у хворих на хронічний гепатит С на тлі противірусної терапії: діагностика та лікування / О.М. Зінчук // Гепатологія. - 2013. - № 1(19). С. 18-25.

7. Tomer Y. Interferon alpha treatment and thyroid dysfunction / Y. Tomer, J.T. Blackard, N. Akeno // Endocrinol. Metab. Clin. North. Am. - 2007. - Vol. 36, N 4. - P. 1051-1066.

8. Agnello V. Extrahepatic disease manifestations of HCV infection: some current issues / V. Agnello, F. De Rosa // J. Hepatol. - 2004. Vol. 40. - P. 341-352.

9. Castillo I. Hepatitis C virus replicates in peripheral blood mononuclear cells of patients with occult hepatitis C virus infection / I. Castillo, E. Rodriguez-Inigo, J. Bartolome // Gut. - 2005. - Vol. 54, N 5. - P. 682-685.

10. Holz L.E. B-cell homeostasis in chronic hepatitis $C$ virus related mixed cryoglobulinemia in maintained through naive B-cell apoptosis / L.E. Holz, J.C. Yoon, S. Raghuraman // Hepatology. - 2012.- Vol. 56 N 5. - P. 1602-1610.

11. Sautto G. Molecular signatures of hepatitis C virus (HCV)induced type II mixed cryoglobulinemia / G. Sautto, N. Mancini, M. Clementi // Hepatology. - 2012. - Vol. 4. - P. 2924-2944.

\section{References}

1. Holubovska, O.A. (2008). Epidemiolohiia ta pryrodnyi perebih hepatytu $C$ [Epidemiology and natural course of hepatitis C]. Klinichna endokrynolohiia ta endokrynna khirurhiia, 4, 1-3 [in Ukrainian].

2. Marcellin, P., Asselah, T. (2014). Viral hepatitis: impressive advances but still a long way to eradication of the disease. Liver International, 34 (1), 1-3.

3. Stefanova-Petrova, D.V., Tzvetanska, A.H., \& Naumova, E.J. (2007). Chronic hepatitis C virus infection: prevalence of extrahepatic manifestations and association with cryoglobulinemia in Bulgarian patients. J. Gastroenterol., 13 (48), 6518-6528.

4. Lee, M.-H., Yang Hwai-I., \& Lu Sheng-Nan (2012). Chronic hepatitis $C$ virus infection increases mortality from hepatic and extrahepatic diseases: a community-based long-term prospective study. J. Infect. Dis., 206, 469-477.

5. Antonelli, A., Ferri, C., \& Pampana, A. (2004). Thyroid disorders in chronic hepatitis C. Am. J. Med., 117, 10-13.

6. Zinchuk, O.M. (2013). Urazhennia shchytovydnoi zalozy u khvorykh na khronichnyi hepatyt $C$ na tli protyvirusnoi terapii: diahnostyka ta likuvannia [Thyroid damage in patients with chronic hepatitis $C$ on the background of antiviral therapy: diagnosis and treatment]. Hepatolohiia, 1 (19), 18-25 [in Ukrainian].

7. Tomer, Y., Blackard, J.T., \& Akeno, N. (2007). Interferon alpha treatment and thyroid dysfunction. Endocrinol. Metab. Clin. North. Am., 36 (4), 1051-1066.

8. Agnello, V., \& De Rosa, F. (2004). Extrahepatic disease manifestations of HCV infection: some current issues. J. Hepatol., 40, 341-352.
12. Dustin L.B. Flying under the radar: the immunobiology of hepatitis C. / L.B. Dustin, C.M. Rice // Ann. Rev. Immunol. - 2007. Vol. 25. - P. 71-99.

13. Muratori P. Non-organ-specific autoantibodies in children with chronic hepatitis $\mathrm{C}$ : clinical significance and impact on interferon treatment / P. Muratori, L. Muratori, G. Verucchi // Clin. Infect. Dis. - 2003. - Vol. 37. - P. 1320-1326.

14. Himoto T. Extrahepatic manifestations and autoantibodies in patients with hepatitis C virus infection / T. Himoto, T. Masaki // Clin Dev. Immunol. - 2012. - Sep. 5.

15. Ghany M.G. Diagnosis, management, and treatment of hepatitis C: an update / M.G. Ghany, D.B. Strader, D.L. Thomas // Hepatology. - 2009. - Vol. 49. - P. 1335-1374.

16. Серов В.В. Хронический вирусный гепатит / В.В. Серов 3.Г. Апросина. - М.: Медицина, 2004. - 232 с.

17. Sene D. Hepatitis C virus-associated extrahepatic manifestations: a review / D. Sene, N. Limal, P. Cacoub // Metabolic Brain Disease. - 2004. - Vol. 19. - P. 357-381.

9. Castillo, I., Rodriguez-Inigo, E., \& Bartolome, J. (2005). Hepatitis $C$ virus replicates in peripheral blood mononuclear cells of patients with occult hepatitis C virus infection. Gut, 54 (5), 682-685.

10. Holz, L.E., Yoon, J.C., \& Raghuraman, S. (2012). B-cell homeostasis in chronic hepatitis $\mathrm{C}$ virus related mixed cryoglobulinemia in maintained through naive B-cell apoptosis. Hepatology, 56 (5), 1602-1610.

11. Sautto, G., Mancini, N., \& Clementi, M. (2012). Molecular signatures of hepatitis $\mathrm{C}$ virus ( $\mathrm{HCV}$ )-induced type II mixed cryoglobulinemia. Hepatology, 4, 2924-2944.

12. Dustin, L.B., \& Rice, C.M. (2007). Flying under the radar: the immunobiology of hepatitis C. Ann. Rev. Immunol., 25, 71-99.

13. Muratori P., Muratori, L., \& Verucchi, G. (2003). Non-organspecific autoantibodies in children with chronic hepatitis C: clinical significance and impact on interferon treatment. Clin. Infect. Dis., 37, 1320-1326.

14. Himoto, T., Masaki, T. (2012). Extrahepatic manifestations and autoantibodies in patients with hepatitis $\mathrm{C}$ virus infection. Clin. Dev. Immunol., Sep. 5.

15. Ghany, M.G., Strader, D.B., \& Thomas, D.L. (2009). Diagnosis, management, and treatment of hepatitis C: an update. Hepatology, 49, 1335-1374.

16. Serov, V.V., \& Aprosyna, Z.H. (2004). Khronicheskyi virusnyi gepatit [Chronic viral hepatitis]. Moscow: Meditsyna [in Russian].

17. Sene, D., Limal, N., \& Cacoub, P. (2004). Hepatitis C virusassociated extrahepatic manifestations: a review. Metabolic Brain Disease, 19, 357-381. 


\section{DAMAGE THYROID IN PATIENTS WITH CHRONIC HEPATITIS C AND ITS RELATIONSHIP WITH CHANGES NON- SPECIFIC AUTOANTIBODIES}

Yu.Yu. Riabokon

Zaporizhzhia State Medical University

SUMMARY. Chronic hepatitis $C$, unlike hepatitis of other etiology, is characterized by a high incidence of extrahepatic manifestations. The role of immune disturbances in the development of HCV-associated disorders is being studied.

The aim of the work - to identify features of thyroid damage in patients with chronic hepatitis $C$ and to investigate their relationship with changes of nonspecific autoantibodies.

Patients and Methods. The study included 225 patients with chronic hepatitis $C$. For the diagnosis of thyroid damage we examined the contents of serum thyroidstimulating hormone, free triiodothyronine, free thyroxine, antibodies to thyroid peroxidase, antibodies to thyroglobulin. Special methods of investigation included determination of the content in the serum of antinuclear antibodies, rheumatoid factor, cardiolipin IgM and IgG, circulating immune complexes.

Results. In $19.6 \%$ of patients with chronic hepatitis C thyroid damage was developed which is manifested by changes in blood content of thyroid-stimulating hormone, free triiodothyronine and thyroxine, present only nonspecific autoantibodies or combination of these changes. The development of hypothyroidism was dominated (68.2\%). The defeat of thyroid damage develops most often in women than in men $(32.1 \% 8.4 \%, p<0.01)$. In patients with chronic hepatitis $C$ with thyroid damage, in contrast to patients without this manifestation, we often identify cardiolipin IgM and IgG antibodies, antinuclear antibodies, higher levels of cardiolipin IgM and IgG. The level of antibodies to thyroid peroxidase correlated $(p<0.01)$ with the content of rheumatoid factor $\lg M(r=+0.66)$ and cardiolipin IgM $(r=+0.39)$. A direct correlation is revealed between the quantitative content of antibodies to thyroid peroxidase and the content of rheumatoid factor IgM $(r=+0.66 ; p<0.01)$, the content of cardiolipin IgM $(r=+0.39 ; p<0.05)$, confirming the role of autoimmunity in the formation of $\mathrm{HCV}$-associated lesions of the thyroid gland.

Conclusions. In every fifth patient with chronic hepatitis $C$ thyroid damage is developed, which is often characterized as hypothyroidism. In the presence of thyroid damage in patients with chronic hepatitis $C$ cardiolipin IgM and IgG antibodies, antinuclear antibodies are often detected. The level of antibodies to thyroid peroxide correlated with the content of rheumatoid factor of IgM and cardiolipin IgM.

Key words: chronic hepatitis C; thyroid; non-specific autoantibodies.

Відомості про автора:

Рябоконь Юрій Юрійович - д-р мед. наук, доцент кафедри дитячих інсекційних хвороб Запорізького державного медичного університету, Україна, E-mail: RyabokonZSMU@mail.ru

Information about author:

Riabokon Yu.Yu. - MD, Associate Professor of the Department of Pediatric Infectious Diseases, Zaporizhzhia State Medical University, Ukraine, E-mail: RyabokonZSMu@mail.ru

Конфрлікт інтересів: немає.

Authors have no conflict of interest to declare.

Отримано 20.12.2016 р. 